\title{
Effect of Time of Harvesting on Physical and Chemical Properties of Soybean (Glycine max M.) Seed
}

\author{
Ashvini Pandit Gaikwad ${ }^{1 *}$ and R.W. Bharud ${ }^{2}$ \\ Department of Agricultural Botany, Discipline Seed Science and Technology, MPKV, \\ Rahuri, Ahmednagar-413722, Maharashtra, India \\ *Corresponding author
}

\begin{tabular}{|c|c|}
\hline & A B S T R A C T \\
\hline \multicolumn{2}{|l|}{ Keywords } \\
\hline $\begin{array}{l}\text { Soybean, } \\
\text { Harvesting, } \\
\text { Protein, Oil and } \\
\text { reducing sugar. }\end{array}$ & \multirow{4}{*}{$\begin{array}{l}\text { Four varieties of soybean viz., KDS-837, KDS-798, JS-335 and DS-9712 } \\
\text { were grown to determine the effect of time of harvesting on its physical and } \\
\text { chemical properties. The hundred seed weight of soybean significantly } \\
\text { decreased after physiological maturity. The electrical conductivity of seed } \\
\text { was significantly increased after physiological maturity. The protein, oil } \\
\text { and reducing sugar of soybean seeds also increased after physiological } \\
\text { maturity. }\end{array}$} \\
\hline Article Info & \\
\hline $\begin{array}{l}\text { Accepted: } \\
12 \text { March } 2017\end{array}$ & \\
\hline $\begin{array}{l}\text { Available Online: } \\
10 \text { April } 2017\end{array}$ & \\
\hline
\end{tabular}

\section{Introduction}

Soybean is one of the most important protein and oil seed crop throughout the world. Soybean has tremendous potential to arrest protein-calories malnutrition in India. The demand for soybean protein is relatively high because of the high cost of other sources of protein such as meat, eggs etc. (Adeyeye et $a l .$, 2014). It is a major oilseed crop next to groundnut and mustard in India.

In addition to providing calories, it is also a rich source of minerals and vitamins. The proximate composition of soybean varies with the geographical area, variety and the stage of maturity (Hegazi et al., 1976). Investigations on the effect of time of harvesting on various physical and chemical properties of soybean seed were found to be scarce; hence the present investigation was carried out.

\section{Materials and Methods}

The soybean varieties viz., KDS-837, KDS798, JS-335 and DS-9712 were grown at PGI Research Farm, MPKV, Rahuri, Maharashtra, India in a Factorial Randomized Block Design with three replications with standard crop practices during year 2014-2015. Harvesting was carried out at physiological maturity $\left(\mathrm{H}_{1}\right)$, five days after physiological maturity $\left(\mathrm{H}_{2}\right)$, ten days after physiological maturity $\left(\mathrm{H}_{3}\right)$ and fifteen days after physiological maturity $\left(\mathrm{H}_{4}\right)$. Weight of randomly selected hundred seeds from pods 
of each treatment in each replication was recorded and represented as hundred seed weight (g). For measuring the electrical conductivity of seed three replications each of 25 seeds randomly selected from each treatment and soaked in $75 \mathrm{ml}$ of distilled water at $25^{\circ} \mathrm{C}$ for 24 hours. The solution and seeds were gently swirled for 10 to 15 seconds prior to evaluation. The electrical conductivity of the solution was measured by using conductivity meter having cell constant one and expressed as mmhos/cm/g (Loeffler et al., 1988). The seed protein, oil (per cent) and reducing sugar content $(\mathrm{g} / 100 \mathrm{~g})$ was determined by Near Infrared Transmittance (NIT) instrument. The $250 \mathrm{~g}$ of soybean seeds from each treatment were placed in an NIT inlet in three replications. The seed protein, oil were expressed in percentage and sugar content in $\mathrm{g} / 100 \mathrm{~g}$.

The data obtained on field trial were interpreted on the basis of FRBD observations of different soybean cultivars. The data was analyzed statistically as per the procedure given by Panse and Sukhatme (1995). The data on laboratory determination were analysed by using FCRD method as described by Snedecor and Cochran (1967).

\section{Results and Discussion}

\section{Hundred seed weight}

The hundred seed weight as influenced by harvesting stages exhibited significant differences (Fig. 1). The significantly highest hundred seed weight was observed at $\mathrm{H}_{1}(\mathrm{PM})$ (32.29, 32.03 and $32.16 \mathrm{~g}$ ) during 2014, 2015 and on pooled basis, respectively. The significantly lowest hundred seed weight was recorded at $\mathrm{H}_{4}$ (15 DAPM) (14.61, 14.71 and $14.66 \mathrm{~g})$ during 2014, 2015 and on pooled basis, respectively. The seed size in terms of hundred seed weight was found to be decreased with delay in harvesting after physiological maturity. Reduction in hundred seed weight observed from PM $\left(\mathrm{H}_{1}\right)$ to 15 DAPM $\left(\mathrm{H}_{4}\right)$ due to the decrease in moisture content of seeds that resulted into loss of seed weight and drying of seed. Hundred seed weight is related with moisture content of seed. Hundred seed weight increased with increase in moisture content and decreased with decrease in moisture content of seed. Similar, results were also reported by Zafar et al., (2008), Bara et al., (2013), Gaikwad and Bharud (2014).

\section{Electrical conductivity of seed}

The data on electrical conductivity of seed as influenced by harvesting stages exhibited significant differences (Fig. 2). The statistically highest electrical conductivity of seed $(83.50,84.00$ and $83.75 \mathrm{mmhos} / \mathrm{cm} / \mathrm{g}$ ) during 2014, 2015 and on pooled basis respectively was recorded at $\mathrm{H}_{4}$ (15 DAPM). The statistically lowest electrical conductivity of seed $(63.75,63.25$ and $63.50 \mathrm{mmhos} / \mathrm{cm} / \mathrm{g})$ during 2014, 2015 and on pooled basis respectively was recorded at $\mathrm{H}_{1}(\mathrm{PM})$.

Thus, the electrical conductivity of seed was found to be increased with delay in harvesting beyond physiological maturity. There was an increase in electrical conductivity of seeds after physiological maturity. Growing trend of electrical conductivity of seeds with delay in harvest and with decrease in moisture content of seeds after physiological maturity, it indicates that seed possess highest vigour at physiological maturity $\left(\mathrm{H}_{1}\right)$ afterward it goes on decreasing. Similar results were reported by Gris and Pinho (2011), Hampton et al., (1992), Marcos-Filho et al., (1994) and Oliveira et al., (2014).

\section{Seed protein content}

The data on seed protein content as influenced by harvesting stages exhibited significant 
differences (Fig. 3). The statistically highest seed protein content $(38.58,38.33$ and 38.46 per cent) during 2014, 2015 and on pooled basis respectively was recorded at $\mathrm{H}_{4}(15$
DAPM). The statistically lowest seed protein content was recorded at $\mathrm{H}_{1}(\mathrm{PM})$ (30.33, 30.50 and 30.42 per cent) during 2014, 2015 and on pooled basis, respectively.

Fig.1 Effect of harvesting stages on hundred seed weight (g) of soybean varieties

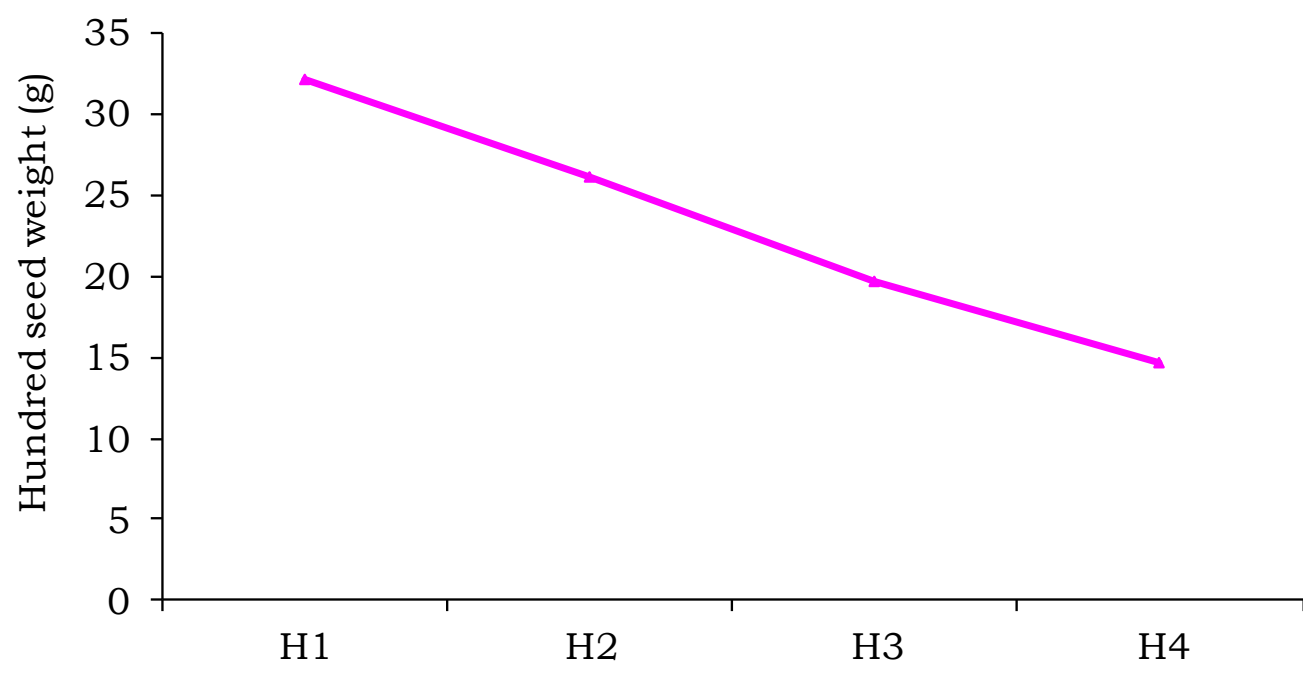

Fig.2 Effect of harvesting stages on electrical conductivity of seed $(\mathrm{mmhos} / \mathrm{cm} / \mathrm{g})$ of soybean varieties

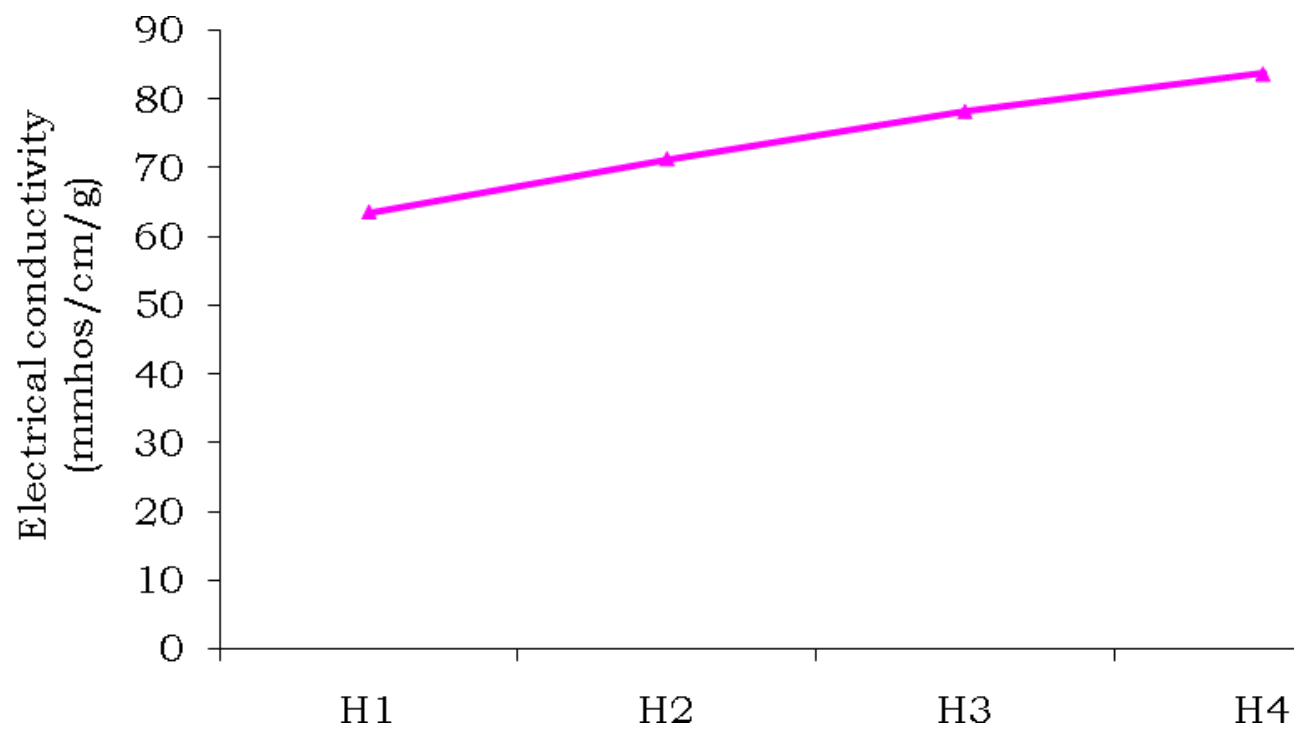


Fig.3 Effect of harvesting stages on seed protein content (per cent) of soybean varieties

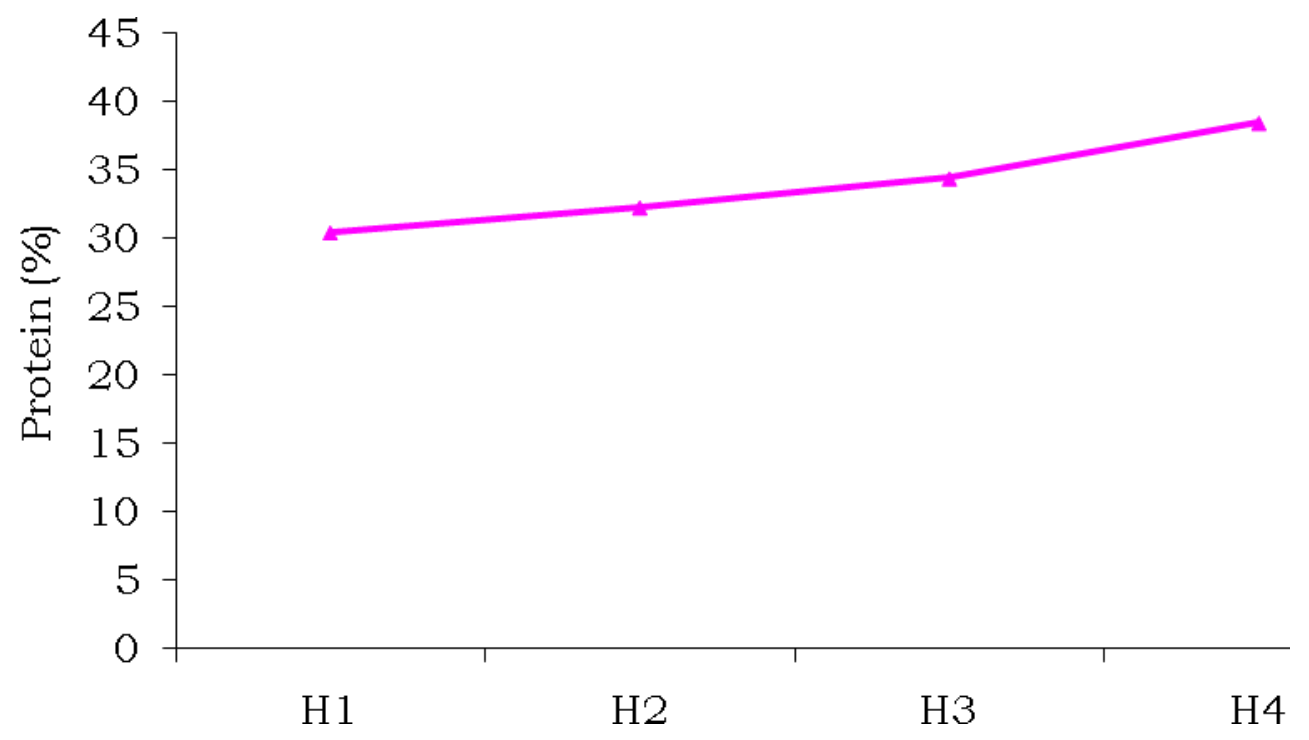

Fig.4 Effect of harvesting stages on seed oil content (per cent) of soybean varieties

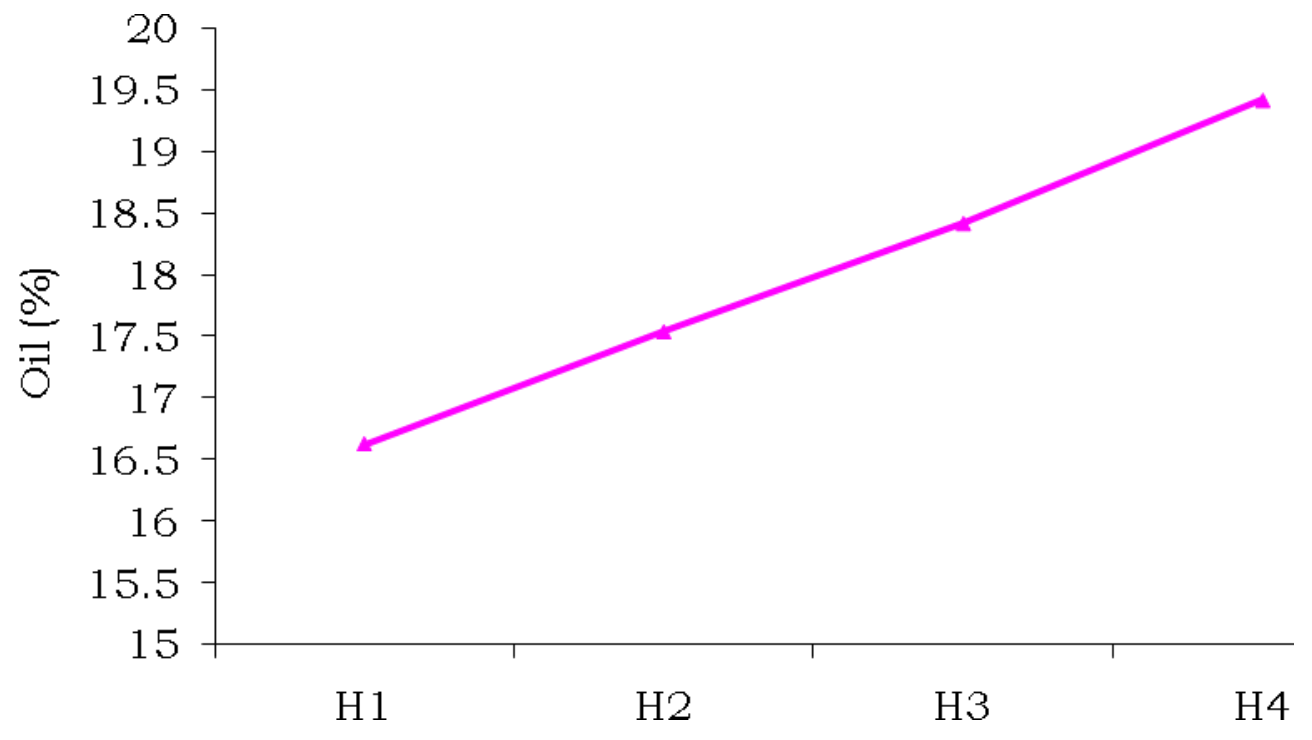


Fig.5 Effect of harvesting stages on reducing sugar $(\mathrm{g} / 100 \mathrm{~g})$ content in seed of soybean varieties

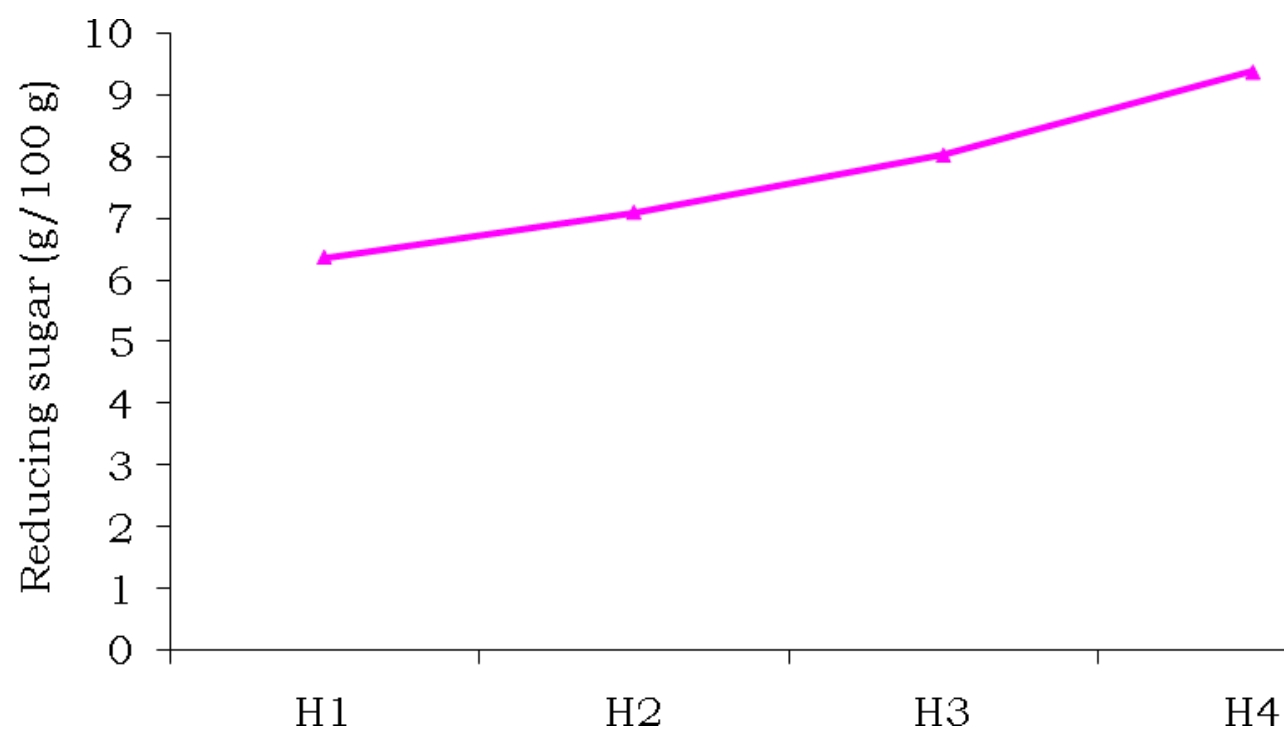

\section{Seed oil content}

The data on seed oil content as influenced by harvesting stages exhibited significant differences (Fig. 4). The statistically highest seed oil content (19.42 per cent) during 2014, 2015 and on pooled basis was recorded at $\mathrm{H}_{4}$ (15 DAPM). The statistically lowest seed oil content was recorded at $\mathrm{H}_{1}(\mathrm{PM})(16.58$, 16.67 and 16.63 per cent) during 2014, 2015 and on pooled basis, respectively.

\section{Seed reducing sugar content}

The data on seed reducing sugar content as influenced by harvesting stages exhibited significant differences (Fig. 5). The statistically highest seed reducing sugar content $(9.61,9.14$ and $9.38 \mathrm{~g} / 100 \mathrm{~g})$ during 2014, 2015 and on pooled basis respectively was recorded at $\mathrm{H}_{4}$ (15 DAPM). The statistically lowest seed reducing sugar content was recorded at $\mathrm{H}_{1}(\mathrm{PM})(6.29,6.45$ and $6.37 \mathrm{~g} / 100 \mathrm{~g}$ ) during 2014, 2015 and on pooled basis, respectively. Result showed that protein, oil and reducing sugar content of seed found to be increased after PM $\left(\mathrm{H}_{1}\right)$. Growing trend of protein, oil and reducing sugar with the decrease in the moisture content of seeds i.e. protein, oil and reducing sugar content or accumulation in seed increase as the seed dry weight increases. Similar results were reported by Thompson and Kieiman (1988), Wilson (2004), Kumar et al., (2006), Sowmya et al., (2012), Gaikwad (2014) and Tutu (2014).

In conclusion, the results indicated a positive effect of harvesting time on the different physical and chemical properties of soybean seed. Careful monitoring of the harvest time properties of soybean seed of different varieties will help to determine optimum harvest times.

\section{References}

Adeyeye, A.S., Togun, A.O., Akanbi, W.B., Adepoju, I.O. and Ibirinde, D.O. 2014. Pod shattering of different soybean varieties, as affected by some growth and yield parameters. Int. J. Agric. Policy Res., 2(1): 010-015.

Bara, N., Khare, D. and Shrivastava, A.N. 2013. Studies on the factors affecting pod 
shattering in soybean. Indian J. Genet., 73(3): 270-277.

Gaikwad, A.P. 2014. Effect of harvesting stages on protein, oil and carbohydrate content of groundnut (Arachis hypogaea L.) seeds. International J. Plant Protection, 7(1): 250-252.

Gaikwad, A.P. and Bharud, R.W. 2014. Effect of harvesting stages on seed quality parameters of groundnut (Arachis hypogaea L.). Int. J. Plant Sci., 9(1): 196198.

Gris, C.F. and Pinho, E.V.R. 2011. Physiological quality of conventional and RR soybean seeds associated with lignin content. Soybean Physiol. Biochem., www.intechopen.com.

Hampton, J.G., Johnstone, K.A. and Euaumpon, V. 1992. Bulk conductivity test variables for mungbean, soybean and french bean seed lots. Seed Sci. Technol. Zurich., 20(3): 677-686.

Hegazi, S.M., Gabriel, G.N., Teha, R.A. and Shehata, O 1976. Comparative studies on some leguminous protein sources and soybean proteins, Zeitrichrift Fuer Ernaeh Rung Swisseacheft, 15(2): 177-181.

Kumar, V., Rani, A., Billore, S.D. and Chauhan, G.S. 2006. Physico-chemical properties of immature pods of Japanese soybean cultivars. Int. J. Food Properties, 9: $51-59$

Loeffler, T.M., Tekromy, D.M. and Egli, D.B. 1988. The bulk conductivity test as an indicator of soybean seed quality. J. Seed Tech., 12(1): 37-53.

Marcos-Filho, J., Chamma, H.M.C.P., Casagrande, J.R.R. and Marcos, E.A. 1994. Effect of harvesting time on seed physiological quality, chemical composition and storability of soybeans. Sci. Agric., 51: 298-304.

Oliveira, C.M.G., Krzyzanowski, F.C., Oliveira, M.C.N., França-Neto, J.B. and Henning, A.A. 2014. Relationship between pod permeability and seed quality in soybean. J. Seed Sci., 36(3): 273-281.

Panse, V.G. and Sukhatme, P.V. 1995. Statistical methods for agricultural workers. ICAR, New Delhi.

Snedecor, G.W. and Cochran, W.G. 1967. Statstical Methods chapter 12.

Sowmya, K.J., Rame Gowda, Balakrishna, P. and Gururaja Rao, M.R. 2012. Effect of fruit maturity stages on seed quality parameters in Jatropha (Jatropha curcas). Indian J. Plant Sci., 1(1): 85-90.

Thompson, A.E. and Kieiman, R. 1988. Effect of seed maturity on seed oil, fatty acid and crude protein content of eight Cuphea species. JAOCS, 65(1): 139-146.

Tutu, I.O. 2014. Effects of harvesting stages and periods of seed storage on seed quality characteristics of three soybean (Glycine $\max$ (L.) Merrill) varieties. Thesis of Kwame Nkrumah University of Science and Technology, Kumasi, Ghana.

Wilson, R.F. 2004. Seed composition. Soybeans: Improvement, Production and Uses. American Society of Agronomy, Crop Science Society of America and Soil Science Society of America, Madison, W.I., 3: 621-677.

Zafar, I., Muhammad Arshad, Muhammad Ashraf, Tariq Mahmood and Abdul Waheed. 2008. Evaluation of Soybean [Glycine $\max (\mathrm{L}$.$) Merrill] germplasm for$ some important morphological traits using multivariate analysis. Pak. J. Bot., 40(6): 2323-2328.

\section{How to cite this article:}

Ashvini Pandit Gaikwad and R.W. Bharud. 2017. Effect of Time of Harvesting on Physical and Chemical Properties of Soybean (Glycine max M.) Seed. Int.J.Curr.Microbiol.App.Sci. 6(4): 1092-1097. doi: https://doi.org/10.20546/ijcmas.2017.604.136 